\title{
JUURNAL.RU
}

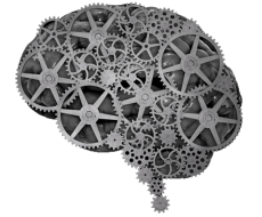

COMPANY GROUP "INTELLEKT"

\author{
Гебенова О.Д., Узденова Ф.М. \\ Карачаево-Черкесский государственный университет имени У.Д. Алиева \\ Карачаевск, Россия
}

doi: 10.18411/1j2016-4-41

\section{Основные факторы и направления туризма в Карачаево-Черкесской республике}

Карачаево-Черкессия, eе богатейшая природа издавна привлекали путешественников и ученых. Впервые о природе Кавказа, в частности об Эльбрусе, из европейских источников упоминает в 479 г. до н. э. трагедия «Прикованный Прометей». Не обошло вниманием территорию КарачаевоЧеркесии средневековье (в книге «Большому чертежу»). Летопись природы велась непрерывно. Исследования здесь проводили многие ученые. Природа нашего края не оставляет равнодушным никого, кто бы с ней не познакомился.

В России нет такого места, в котором бы так удачно сочетались разнообразные факторы, способствующие лечению и оздоровлению человека, как в Карачаево-Черкесии. Курортные рекреационные природные ресурсы могут стать тем локомотивом, который вытянет всю экономику республики.

Курорт слово немецкое и в дословном переводе означает «лечение местностью». Подразумевается местность с природными лечебными свойствами. Слово «рекреация» латинское и означает «восстановление здоровья», «место отдыха» и сам отдых людей. Часто курорт и рекреация сочетаются в одном месте.

Теберда как аул известен еще с 1868 года. Это единственный горноклиматический курорт России, расположенный на высоте 1300-1400 метров на уровнем моря и окруженный горными массивами, покрытыми хвойными и 
лиственными лесами. Город обладает уникальными климатическими условиями: относительно прохладный, сухой, чистый, ионизированный воздух, большое количество солнечных дней, мягкая зима. С достаточно устойчивым снеговым покровом определили его специализацию. После съезда русских врачей 1910 году здесь стали строится частные дачи- санатории для больных туберкулезом легких. На базе этих дач в дальнейшем развернулось строительство санаториев. Частично реализуется в республике уже в наши дни - климатотерапия и частично бальнеотерапия. Бальнеотерапия означает лечебное купание в минеральной воде разного температурного режима и дозированное питье ее по назначению врачей, другие водные процедуры.

Грязелечением на базе целебных грязей Большого и Малого Соленных озер (Баталпашинские озера) занимались еще в начале 20-го века. В середине века Большое озеро было опреснено кубанской водой. Грязи Малого Соленого озера по своему составу идентичны известному Тамбуканскому озеру Пятигорья. Пелотерапия обычно сочетается с другими видами курортного лечения. Гряз, как правило, доставляется в «готовом виде» в курортные учреждения от ее месторождений на значительные расстояния.

В лечебном процессе имеют большое значение фитоциды- летучие вещества, убивающие бактерии. Это продукты жизнедеятельности растений, ощущаемые человеком как их запахи. Из имающихся здесь санаториев широко известны санатории «Горное ущелье», «Клухори» и др.

Теберда - не только всемирно известный курорт. Вместе с расположенной выше по течению реки Домбайской поляной город составляет единый комплекс горного туризма.

Домбай является одним из старейших среди горнолыжных курортов России. Богата и неповторима здешняя природа. Еще в позапрошлом веке путешественники побывавшие тут писали о том, что самые известные в Альпах места не выдерживают сравнения с этими, с необыкновенной красотой и первозданной дикостью. Сама природа создала здесь все условия для занятия 
туризмом, альпинизмом, горными лыжами и сноубордом. Канатная дорога обеспечивает все условия для развития горнолыжного спорта.

Архыз сегодня - это быстро развивающийся центр туризма. Тысячи людей разных возрастов и интересов приезжают сюда летом и зимой, осенью и весной. Опытные инструкторы обучают их премудростям походной жизни, основам горнолыжной техники, водят в горы к нетронутым снегам, к голубым озерам.

Здесь работы по оценкам природных комплексов Архыза для рекреационных целей показали, что вся территория этого района может быть вовлечена в сферу рекреационной деятельности, здесь нет пространств, которые не несли бы рекреационных функций. Многие территории пригодны для целого ряда рекреационных занятий и могут одновременно выполнять несколько рекреационных функций.

Рекреационные возможности республики чрезвычайно разнообразны. Это и пешие походы разной сложности в горах и занятии горнолыжным спортом, и верховые прогулки, и автобусные маршруты к памятникам природы и историческим местам республики, спортивная охота, рыбалка и т.п.

Рельеф республики служит потенциальным ресурсом для развития массового горно-пешеходного, верхового-конного туризма, спелеотуризма, занятий скалолазанием. Географическое строение и современные геоморфологические процессы создают предпосылки развития познавательных экскурсий. Здесь насчитывается около 170 категорийных вершин и перевалов, позволяющих совершать сложные туристические походы. Есть перевалы, доступные для массового туризма, через которые проходили всесоюзные туристские маршруты с выходом к черному морю. Это Клухорский (2781 м.), Пхия (2100 м.), Дамхурц (1540 м.), Марухский (2739 м.) и Санчарский (2595м.)

Склоны, не покрытые лесом и имеющие удобный для катания на лыжах и санях угол наклона, в зимнее время превращаются в слаломные и санные трассы. Популярными местами для этого служат Домбай и Архыз. Однако лавинная и селевая опасность, камнепады угрожают постройкам и отдыхающим. 
Реки Карачаево-Черкесии обладают следующими технологическими необходимыми ресурсами:

а) быстрое течение и большие расходы воды в весенне-летнее время (до 100 дней);

б) наличие в реках форели позволяет заниматься любительским ловом рыбы;

в) большое количество порогов и водопадов создает лечебные и оздоровительные ресурсы. Способствующими рекреационными ресурсами выступает эстетическая ценность речных пейзажей.

Лимитирующими рекреационную деятельность факторами являются: низкие температуры воздуха в горной части рек препятствующие развитию пляжно-купального отдыха; почти полное отсутствие пляжей и низкие температуры гальки; частые паводки, опасные для ночевок в поймах рек и переправ туристских групп.

На территории района около 1000 озер. Это в основном горные озера (ри! 11). Большая часть связана с современными и древними ледниками, расположенными в карах и ледниковых долинах на высотах $1300-12800$ м. В среднегорных районах распространены обвальные и карстовые озера. Озера Тебердинской группы - каровые я запрудные моренные. Максимальные температуры воды приходятся на август-сентябрь и доходят в некоторых озерах до 16 - $19^{\circ} \mathrm{C}$, когда можно купаться. Большая часть озер покрывается сплошным ледяным покровом зимой. Почти все высокогорные озера бедны жизнью. Рыба в них отсутствует.

В Карачаево-Черкесском рекреационном районе более 200 минеральных источников различного состава. Наиболее известны источники Гаралы-Кол, Махарские, Лаштракские, Красногорские, которые выходят вблизи дорог и туристских троп. Только в северном Приэльбрусье 30 источников минеральных вод. 
Большое разнообразие форм и видов растений, эндемизм флоры являются технологически необходимыми PP для ботанических, географических экскурсий, любительских занятий (сбор лекарственных растений, плодов), фотоохоты. Для каждого вида деятельности удобен свой сезон. Ботанические экскурсии возможно проводить круглый год, но лучшее время - с мая по сентябрь. Для сбора плодов богаче вторая половина лета и осень.

Леса и цветущие луга богаты фитонцидами и могут быть местами лечения и оздоровления людей.

Растительность придает красоту пейзажам и является способствующим РР для всех видов отдыха - туризма, экскурсий, лыжных прогулок, отдыха выходного дня.

Лес выступает способствующим РР при организации туристских ночевок, временных стационарных лагерей отдыха, туристских слетов и других видов отдыха.

При этом растительность расценивается как технологически необходимый PP.

Растительность может выступать и лимитирующим некоторые виды рекреационной деятельности факторам. Так, колючие сорные растения делают трудно проходимыми луга и лесные поляны. Также влияют заросли крапивы, борщевника и других ядовитых растений. Сильно пахнущие во время цветения азалия, лилия и другие эфироносы вызывают головную боль.

Животный мир интересен в экскурсионном отношении, для фотоохоты и спортивной охоты. Воспой возможны орнитологические экскурсии, во время пения птиц, а зимой - следопытские прогулки по свежему снегу.

В пределах Карачаево Черкесииобитают 137 видов позвоночных животных, из них 36 млекопитающих, 87 птиц, 7 пресмыкающихся, 4 земноводных, 3 вида рыб, в горах огромное количество насекомых. Помимо этого 80 видов птиц бывают на пролёте, а также кочуют или зимуют.

Крупные млекопитающие, особенно эндемики, служат объектами 
экскурсий, наблюдений за их поведением, специальной подкормки и охраны. Для этих видов рекреационной деятельности животные являются технологически необходимым РP.

В пределах Карачаево-Черкесского рекреационного района находится 22 охотничьих хозяйства, где по лицензиям разрешается любительская спортивная охота. Организованы охотничьи заказники, где охота запрещена (Архызский, «Дамхурц», Че-ремховский, Учкуланский, Даутское ущелье, Джегонас, Чилийский). В 1936 г. на площади 83 тыс. га был создан Тебердинский государственный заповедник. Он состоит из двух участков - Тебердинского и Архызского. Здесь охраняются эндемичные и редкие виды животных; восстановлен зубр.

Имеются лимитирующие факторы влияния животного мира на рекреацию. В лесу в близи рек в июне, июле наблюдается выплод комаров, которые ограничивают возможности пребывания отдыхающих в лесу.На лугах в солнечные жаркие дни масса слепней, также причиняющих беспокойство туристам и экскурсантам. Опасны встречи с зубрам. В Архызе обитает ядовитая кавказская гадюка.

Карачаево-Черкесия богата памятниками истории и культуры разных эпох. Всего в настоящее время насчитывается: 14 стоянок каменного века, 151 городище, 225 могильников, 25 храмов, 24 башни, 25 каменных статуй, наскальное изображение Христа, датируемая 12 в. н.э.

Большую архитектурную ценность представляет Зеленчукский, Сентинский, Шаонинский храмы, башни Адиюх, Гошаях-кала, Мамия-Кала. В аулах Карт-Джурте, Учкулане, хурзуке, Дауте имеются старинные деревянные постройки, мельницы и другие этнографические объекты.

На территории Карачаево-Черкесского рекреационного района много памятников, хранящих незабываемую славу героев гражданской войны, революции, Великой Отечественной войны. Здесь находится музей-памятник защитникам перевалов Кавказа. 
На территории Архыза работает специальная астрофизическая обсерватория (САО РАН), которая входит в десятку самых крупных в мире. Обсерватория принимает организованные экскурсии.

Учитывая исключительную рекреационную ценность территории республики и сравнивая возможный экономический эффект туристкскорекреационной отрасли с другими отраслями производства, следует отдать предпочтение рекреации. На сегодняшний день туризм- это один из уникальных отраслей современной экономики, нацеленная на удовлетворение потребностей людей, повышения качества жизни населения, защиту окружающей среды и культурного наследия. При этом человеческая деятельность не приводит к истощению природных и культурных ресурсов. Туризм в Карачаево-Черкесии должен стать важной составной частью экономического и социального прогресса республики.

\section{Литература:}

1. Братков В.В., С.И. Салпагарова, Х.И. Узденова. Метеорология и климатология. - Карачаевск, 2005.

2. Котляков В.М., Гуня А.Н., Грачева Р.Г. Тенденции развития ландшафтов Северного Кавказа в условиях меняющегося климата и социальноэкономических трансформаций // Материалы 1 Кавказского Международного экологического форума.- Грозный, 2013.

3. Николаенко Д. В. Рекреационная география. - М., 2008.

4. Савельева В.В., Щитов А.С. Рекреационные ресурсы Архыза. Вопросы рекреационные географии Северного Кавказа. - Ставрополь, 2007.

5. Теберда. Домбай. Архыз: Природа. Исторический очерк. Туристскоэкскурсионные маршруты/ Сост. С. А. Хапаев,- М.: Профиздат, 2008.

6. Эколого-географический атлас Карачаево-Черкесской республики. Ростов н/Д, 2001. 